\title{
Characterization of the Ghost Fusion Method: a Method for Introducing Exogenous Substances into Cultured Cells
}

\author{
Masaru Yamaizumi*, Mitsuru Furusawa**, Tsuyoshi Uchida*, \\ Toshikazu Nishimura*** and Yoshio Okada* \\ *Research Institute for Microbial Diseases, Osaka University, Suita, Osaka, \\ Japan, **Laboratory of Embryology, Department of Biology, Faculty of \\ Science, Osaka City University, Osaka, Japan, and ***Department of Anatomy, \\ Aichi Medical University, Nagakute-cho, Aichi-ken, Japan
}

\begin{abstract}
When erythrocytes were fused to cultured cells with HVJ, hemoglobin in erythrocytes was transferred to the cells. The hemoglobin became uniformly distributed in cells within $5 \mathrm{~min}$, but components of the erythrocyte membranes did not become completely incorporated into recipient-cell membranes for about $2 \mathrm{~h}$. Division of recipient cells was normal but did not start until one day after fusion. Human and guinea-pig erythrocytes had the highest fusion capacities of various animal erythrocytes tested. When these erythrocytes and iodinated bovine serum albumin (BSA) were dialyzed against hypotonic solution, BSA was trapped in erythrocyte ghosts within $30 \mathrm{~min}$, at about $50 \%$ of initial concentration in the dialysis bag. Of BSA trapped in ghosts, $80 \%$ was found in the cytoplasmic fraction and $20 \%$ associated with the membrane fraction. BSA was quite stable in these ghosts. Other proteins with various isoelectric points were also introduced into ghosts, and these proteins were transferred to recipient cells by virus-induced cell fusion of these ghosts. About $80 \%$ of recipient cells in either monolayers or suspensions fused with the ghosts. Use of iodinated BSA showed that $0.25 \%$ of the initial amount of BSA in the dialysis bag was introduced into recipient cells.
\end{abstract}

Since we first reported a method for introducing an exogenous substance into cultured cells by fusion of the cells with erythrocyte ghosts loaded with the substance mediated by HVJ (Sendai virus) (the ghost fusion method) (5), various attempts to improve the method have been made in several laboratories $(11,15,21)$. Loyter et al. (11) and we (15) independently succeeded in introducing exogenous molecules into erythrocyte ghosts, without injuring the ability of the ghosts to fuse, by gradual hemolysis of the erythrocytes in a dialysis bag (22). Further basic information is needed, however, before this method can be used as a routine technique.

The present experiments were carried out to clarify the following points: (1) the optimal conditions for introducing exogenous molecules into the ghosts, (2) the stability of protein molecules introduced into ghosts, and (3) the behavior of recipient cells after fusion with erythrocytes or erythrocyte ghosts.

\section{MATERIALS AND METHODS}

Cells and virus. A mutant of Ehrlich ascites tumor cells (ETC) resistant to 8-azaguanine (16) 
was propagated in the abdomen of ddO mice. The FL cell line, originating from normal human amniotic membrane (2) and a mutant of the mouse $\mathrm{L}$ cell line that is resistant to BudR (14) were cultured in Eagle's MEM supplemented with $10 \%$ calf serum. Both cell line had a high plating efficiency (more than $70 \%$ ) and formed compact colonies. Fresh erythrocytes from various animals were collected in syringes with citrate and washed 3 times with PBS to remove elukocytes. To check their ability to fuse, the erythrocytes were washed once more with BSS-Ca (140 mM NaCl, $5.4 \mathrm{mM} \mathrm{KCl}, 0.34 \mathrm{mM} \mathrm{Na}_{2} \mathrm{HPO}_{4}, 0.44 \mathrm{mM} \mathrm{KH}_{2} \mathrm{PO}_{4}$, and $2 \mathrm{mM} \mathrm{CaCl}_{2}$ buffered with $10 \mathrm{mM}$ Tris- $\mathrm{HCl}$ at $\mathrm{pH}$ 7.6) by centrifugation at $2,000 \mathrm{rpm}$ for $5 \mathrm{~min}$, then suspended at a concentration of $1 \%(\mathrm{v} / \mathrm{v})$ in BSS-Ca. To introduce exogenous proteins into the erythrocyte ghosts, the erythrocytes finally washed with r-PBS (137 mM $\mathrm{KCl}, 2.7 \mathrm{mM} \mathrm{NaCl}, 8.1 \mathrm{mM} \mathrm{Na}_{2} \mathrm{HPO}_{4}, 1.5 \mathrm{mM} \mathrm{KH}_{2} \mathrm{PO}_{4}, 4 \mathrm{mM} \mathrm{MgCl}$, pH 7.4) by centrifugation at 2,000 rpm for $5 \mathrm{~min}$. The resulting erythrocyte pellet was used.

The virus (HVJ-z strain) was propagated, harvested and partially purified as described previously (18). Virus was suspended in $\mathrm{BSS}\left(\mathrm{CaCl}_{2}-\mathrm{free}\right)$, and its titer was measured as hemagglutinating units (HAU) by Salk's pattern method (20). It then was inactivated by UV-irradiation before use (27).

Preparation of loaded erythrocyte ghosts. The method for the preparation of loaded erythrocyte ghosts is described elsewhere (6). In brief, a mixture of $0.2 \mathrm{ml}$ of packed erythrocytes and $1.8 \mathrm{ml}$ of exogenous protein in r-PBS was dialyzed against $480 \mathrm{ml}$ of 6 -fold diluted r-PBS containing $4 \mathrm{mM} \mathrm{MgCl}$ for $30 \mathrm{~min}$ at $4^{\circ} \mathrm{C}$. After further dialysis against $500 \mathrm{ml}$ of PBS for 30 min at room temperature, the erythrocyte ghosts were washed 4 times with PBS by centrifugation at 2,800 rpm for $8 \mathrm{~min}$, and finally were suspended in BSS-Ca at a concentration of $20 \%$ (v/v). Ghosts containing FITC-conjugated BSA (FITC-BSA) were prepared by dialyzing a mixture of $0.2 \mathrm{ml}$ of packed erythrocytes, $1.5 \mathrm{ml}$ of r-PBS and $0.3 \mathrm{ml}$ of FITC-BSA (32 $\mathrm{mg} / \mathrm{ml}, \mathrm{F} / \mathrm{P}=2.1$ ).

Cell fusion. To estimate the fusion capacity of erythrocytes (the ability of erythrocytes to fuse) from various animals and the viability of recipient cells fused with erythrocytes, cells (FL cell line or L cell line) were plated on Falcon plastic dishes ( $30 \mathrm{~mm}$ in diameter) beforehand by incubation for $8 \mathrm{~h}$ at $37^{\circ} \mathrm{C}$. An inoculum of $1 \times 10^{4}$ cells per dish was used to estimate the fusion capacity of erythrocytes, and one of $3 \times 10^{2}$ cells per dish was used to measure the viability of the recipient cells. The dishes were washed once with $2 \mathrm{ml}$ of chilled BSS-Ca, then $1 \mathrm{ml}$ of chilled HVJ (3,000 HAU) was added. After 5-min of incubation at $4{ }^{\circ} \mathrm{C}$, unadsorbed HVJ was washed off and $1 \mathrm{ml}$ of chilled erythrocyte suspension $(1 \%$ for fusion capacity of erythrocytes and $20 \%$ for viability of recipient cells) was added. After 15 -min of incubation at $4{ }^{\circ} \mathrm{C}$, the dishes were further incubated for $20 \mathrm{~min}$ at $37^{\circ} \mathrm{C}$. The erythrocytes then were removed and the recipient cells were cultured in Eagle's MEM supplemented with $10 \%$ calf serum.

To measure the time course of diffusion of the introduced hemoglobin, a mixture of $0.3 \mathrm{ml}$ of a $10 \%$ suspension of ETC, $0.2 \mathrm{ml}$ of a $2 \%$ suspension of erythrocytes and $0.5 \mathrm{ml}$ of inactivated HVJ (500 HAU) was incubated in a test tube shaken first for $20 \mathrm{~min}$ at $4^{\circ} \mathrm{C}$ then $37^{\circ} \mathrm{C}$. After various periods of incubation at $37^{\circ} \mathrm{C}$, the cells were recovered by centrifugation at $4^{\circ} \mathrm{C}$ and the cell pellet was quickly smeared on cover-slips. The cells were air-dried, fixed with methanol then stained with benzidine. To introduce exogenous proteins into the recipient cells, $0.2 \mathrm{ml}$ of a $20 \%$ ghost suspension was used in place of intact erythrocytes.

Benzidine staining. Two methods were used. To estimate the fusion capacity of erythrocytes and the time course of diffusion of the hemoglobin introduced into recipient ETC, a modification of Ralph's method (9), in which cells were fixed with absolute methanol, was used.

To examine the viability of the recipient cells fused with erythrocytes, cells were stained 
without fixation by adding 2 drops of benzidine solution ( 1 part $3 \%$ benzidine in $90 \%$ acetic acid, 5 parts distilled water, and 1 part $30 \% \mathrm{H}_{2} \mathrm{O}_{2}$ ) to dishes containing $2 \mathrm{ml}$ of the cultured medium (wet method) (19). These cells could be stained with Giemsa after fixation with methanol for permanent preparation. In both methods cells containing hemoglobin became brown.

Antibodies. Anti-BSA was a gift from Dr. M. Makino and anti-hen lysozyme was a gift from Dr. Y. Dohi of our institute. These antisera prepared in rabbits were heat-inactivated $\left(56^{\circ} \mathrm{C}, 30 \mathrm{~min}\right)$ and absorbed completely with human erythrocytes before use. Antiserum against human erythrocyte membranes was prepared in rabbits by subcutaneous injection of the water soluble fraction of erythrocyte ghosts with Freund's complete adjuvant (4). The antisera were also heat-inactivated and absorbed with ETC. FITC-conjugated anti-rabbit IgG goat serum was purchased from Miles-Yeda Ltd., Israel. This serum was also absorbed with ETC.

Immunofluorescent staining. To examine the distribution of erythrocyte membrane components on recipient cells, cells (ETC) were fused with erythrocytes by the method used to examine the time course of diffusion of the introduced hemoglobin. After various periods of incubation at $37^{\circ} \mathrm{C}$, cells were centrifuged at $4^{\circ} \mathrm{C}$. The resulting cell pellet was first stained with anti-human erythrocyte membrane rabbit serum for $15 \mathrm{~min}$ at $4^{\circ} \mathrm{C}$, then it was washed twice with cold PBS and stained with FITC-conjugated anti-rabbit IgG goat serum for 15 min at $4^{\circ} \mathrm{C}$. Finally, cells were washed twice with cold PBS and observed under a fluorescent microscope.

To confirm that the sealed ghosts contained exogenous proteins, the ghosts were smeared on a slide-glass and air-dried, then they were fixed with acetone for $10 \mathrm{~min}$ at $-20^{\circ} \mathrm{C}$ and stained with rabbit serum containing the antibodies to these exogenous proteins and FITCconjugated anti-rabbit IgG goat serum for $30 \mathrm{~min}$ at $4^{\circ} \mathrm{C}$. Some ghosts also were stained without acetone-fixation.

Iodination. BSA and rabbit IgG were labelled with ${ }^{125} \mathrm{I}$ by the method of Greenwood et al. (7) with a slight modification. One $\mathrm{mg}$ of the iodinated BSA and of IgG gave $2 \times 10^{8} \mathrm{cpm}$ and $1.5 \times 10^{8} \mathrm{cpm}$, respectively. More than $98 \%$ of the radioactivity could be precipitated with $5 \%$ TCA.

SDS-polyacrylamide gel electrophoresis. Polyacrylamide gel electrophoresis was performed on gels containing $0.1 \%$ SDS, $7.5 \%$ polyacrylamide and $50 \mathrm{mM}$ sodium phosphate buffer, pH 7.2 by the method of Weber and Osborn (24) with slight modifications. The ghost suspension was solubilized with an equal volume of double strength sample application buffer, then $100 \mu \mathrm{l}$ of the mixture was applied to the gels. The radioactivity in 2-mm thick slices of the gels was counted with a Packard 3002 spectrometer.

\section{RESULTS}

Fusion capacities of erythrocytes from different animals. Erythrocytes with a high fusion capacity are required for the efficient introduction of exogenous substances into recipient cells by the ghost fusion method. Therefore, we first estimated the relative ability of erythrocytes from different animals to fuse with recipient FL cells (fusion capacity of erythrocytes). Since hemoglobin is introduced into recipient cells when they fuse with erythrocytes, we measured the extent of cell fusion by staining the cells with benzidine. The fusion capacity of the erythrocytes was expressed as the percentage of benzidine positive cells among the total cells counted. Table 1 shows that human and guinea-pig erythrocytes had the highest 
TABLE 1. FUSION CAPACITIES OF ERYTHROCYTES FROM VARIOUS ANIMALS

\begin{tabular}{lc}
\hline \multicolumn{1}{c}{ Animal } & Fusion Capacity $(\%)^{a}$ \\
\hline human & 26 \\
guinea pig & 23 \\
dog & 13 \\
cow & 11 \\
hamster & 5 \\
chick & 4 \\
sheep & 3 \\
mouse & 2 \\
rat & 2 \\
Chinese hamster & 1 \\
rabbit & 1
\end{tabular}

a Fusion capacities of erythrocytes are expressed as the percentages of FL cells fused with the erythrocytes (see Materials and Methods). 200-600 FL cells were counted.

values. The fusion capacities of human erythrocytes with different ABO blood groups were similar. Therefore, all subsequent experiments were carried out with human erythrocytes, irrespective of their blood type.

Diffusion of erythrocyte membrane antigens and hemoglobin in recipient cells. After fusion of two kinds of cells, the membrane components gradually become intermingled at $37^{\circ} \mathrm{C}$ (3). We examined the time course of diffusion of erythrocyte membrane antigens on recipient cell membranes by staining the cells with anit-human erythrocyte membrane antiserum after various periods of incubation at $37^{\circ} \mathrm{C}$. As shown in Fig. 1, it took about $2 \mathrm{~h}$ for the membrane components to diffuse completely over the recipient cells. The time course of the diffusion of ghost membrane was the same as that of intact erythrocyte membranes (Fig. 1). In contrast, the hemoglobin became evenly distributed in the recipient cells and even was found in the nucleus within $5 \mathrm{~min}$. This rapid diffusion of molecules introduced into recipient cells was

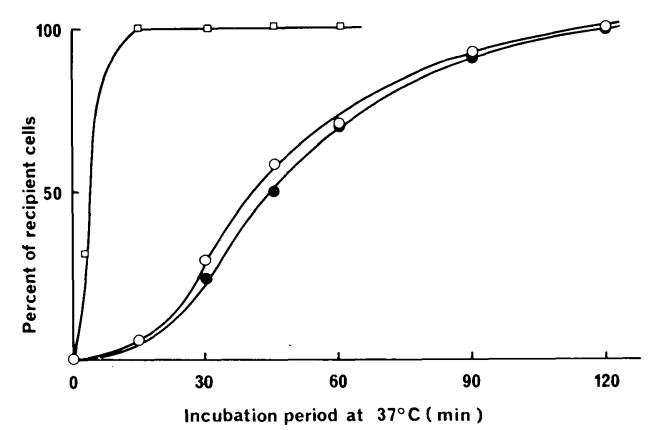

Fig. 1. Time course of diffusion of hemoglobin and erythrocyte membrane antigens in recipient cells. Ehrlich ascites tumor cells were fused with intact erythrocytes or erythrocyte ghosts. $\square$, percent of recipient cells in which hemoglobin diffused completely. $\bigcirc$ and $\boldsymbol{\bullet}$, percent of cells on which erythrocyte membrane antigens diffused completely after fusion with intact erythrocytes and erythrocyte ghosts, respectively. 
confirmed by fluorescence microscopy at 37-C after fusion of ghosts containing FITCBSA with recipient cells (Yamaizumi, Mekada and Okada, unpublished data), although BSA did not penetrate the nucleus (26).

Viability of recipient cells fused with erythrocytes. As the result of fusion with erythrocytes, hemoglobin is introduced into the recipient cells and the components of the erythrocyte membrane are also transferred to the cells. If these events were cytotoxic, the method would not be very useful. Therefore, we measured the viability of the recipient cells after intraspecific combination (human erythrocyteshuman recipient cells) and after interspecific combination (human erythrocytesmouse recipient cells). To examine possible changes in the cell number per colony, recipient cells were inoculated very sparsely (200-300 cells/dish). After they had become attached to the dishes, they were fused with erythrocytes by first adding HVJ, then the erythrocytes. These dishes were stained by the wet benzidine method every day for 3 days, and the cell numbers per colony in the benzidine-positive and benzidine-negative colonies were examined. Table 2 shows that after interspecific combination, recipient cells that had fused with erythrocytes divided normally, but that cell division started about one day after that of unfused cells. Similar results were obtained after intraspecific fusion (Table 2). On the fourth day after cell fusion, benzidine-positive colonies could no longer be detected clearly, because the hemoglobin molecules were diluted geometrically at every cell division.

Effect of the duration of hypotonic treatment on the loading of erythrocyte ghosts.

In the original method, erythrocytes were lysed and loaded directly in a hypotonic solution (5), but the ability of the resulting ghosts to fuse was very low (less than $1 \%$ ). In the improved method, in which erythrocytes were dialyzed against a hypotonic solution (15), the ability of the ghosts to fuse was much higher. Prolonged and drastic treatment of erythrocytes in hypotonic solution may reduce the ability of the resulting ghosts to fuse. In previous studies, we achieved the maximal introduction of IgG into

TABLE 2. DISTRIBUTION OF COLONIES WITH DIFFERENT CELL NUMBERS

\begin{tabular}{|c|c|c|c|c|c|c|c|c|c|c|c|}
\hline \multicolumn{6}{|c|}{$\begin{array}{l}\text { Benzidine-positive colonies } \\
\text { Cell number per colony }\end{array}$} & \multicolumn{6}{|c|}{$\begin{array}{l}\text { Benzidine-negative colonies } \\
\text { Cell number per colony }\end{array}$} \\
\hline Day $^{a}$ & 1 & 2 & 3-4 & $5-8$ & 9-16 & $\operatorname{Day}^{a}$ & 1 & 2 & 3-4 & 5-8 & $9-16$ \\
\hline 0 & 79 & 21 & 0 & 0 & 0 & 0 & 87 & 13 & 0 & 0 & 0 \\
\hline 1 & 36 & 57 & 8 & 1 & 0 & 1 & 39 & 56 & 5 & 0 & 0 \\
\hline 2 & 19 & 55 & 23 & 2 & 0 & 2 & 10 & 32 & 50 & 7 & 1 \\
\hline 3 & 11 & 20 & 45 & 23 & 1 & 3 & 7 & 9 & 31 & 42 & 11 \\
\hline Day $^{b}$ & 1 & 2 & $3-4$ & $5-8$ & & Day $^{b}$ & 1 & 2 & 3-4 & $5-8$ & \\
\hline 0 & 100 & 0 & 0 & 0 & & 0 & 100 & 0 & 0 & 0 & \\
\hline 1 & 81 & 19 & 0 & 0 & & 1 & 56 & 44 & 0 & 0 & \\
\hline 2 & 37 & 50 & 13 & 0 & & 2 & 12 & 65 & 23 & 0 & \\
\hline 3 & 12 & 35 & 46 & 7 & & 3 & 9 & 19 & 53 & 19 & \\
\hline
\end{tabular}

The viability of recipient cells fused with erythrocytes was examined by comparing the cell numbers in colonies of benzidine-positive recipient cells (recipient cells fused with erythrocytes) with those of benzidine-negative ones. 150-250 colonies of each type were examined. The percentage distribution of the colonies with different cell numbers on each day is shown. ${ }^{a}$ FL-human erythrocytes. ${ }^{b}$ L-human erythrocytes. 


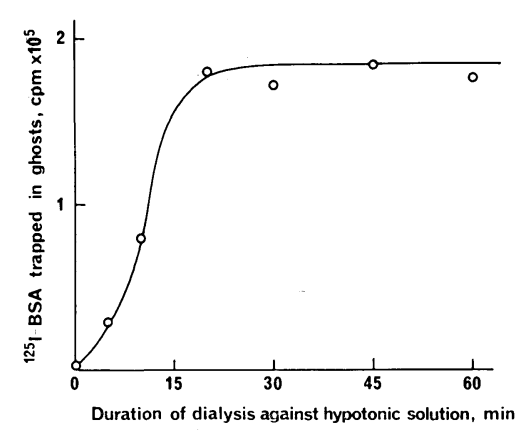

Fig. 2. Effect of the duration of hypotonic treatment on the incorporation of BSA into ghosts. After dialysis against a hypotonic solution for the periods indicated, erythrocytes were further dialyzed against an isotonic solution for $30 \mathrm{~min}$ after which the amount of radioactivity trapped in the ghosts was determined.

ghosts by dialysis against 6 -fold diluted r-PBS (25). In the present study we examined the minimal time required for the maximal introduction of exogenous molecules into ghosts with iodinated BSA. As shown in Fig. 2, the amount of radioactivity trapped in the ghosts reached a plateau within $25 \mathrm{~min}$. When these resealed ghosts were again dialyzed against a hypotonic solution, a little more BSA was sealed into the ghosts. Therefore, a second dialysis does not effectively introduce more molecules into ghosts.

Effect of the concentration of erythrocytes on the amount of exogenous substance trapped by erythrocyte ghosts. In the present study, to prepare erythrocyte ghosts, a $10 \%$ erythrocyte suspension was used as the standard concentration (see Materials and Methods.), but when it is necessary to prepare as many loaded erythrocyte ghosts as possible with a limited amount of exogenous substance, higher concentrations of the erythrocyte suspension must be used. However, the large amounts of hemoglobin released from some of the erythrocytes during hypotonic treatment must result in the inhibition of hemolysis for many other erythrocytes. The amount of exogenous substance trapped in erythrocyte ghosts, therefore, may reach a plateau when the concentration of the erythrocytes exceeds some critical point.

We examined the amounts of IgG trapped in erythrocyte ghosts when a mixture of various concentrations of erythrocytes and a constant amount of iodinated IgG was dialyzed as a model system. Fig. 3 shows that the amounts increased linearly up to $30 \%$ with the increase in the concentration of erythrocytes, then reached a plateau.

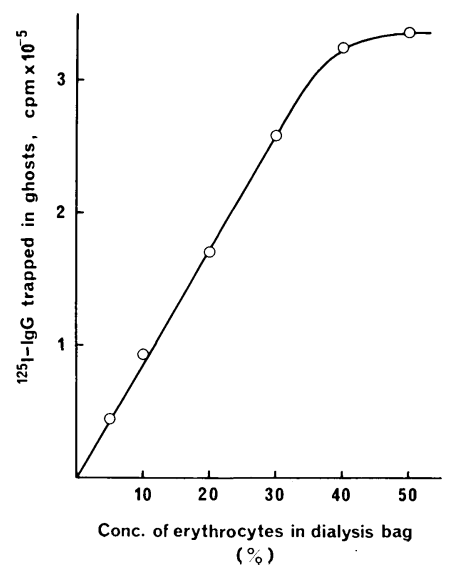

Fig. 3. Effect of the concentration of erythrocytes on the incorporation of IgG into ghosts. Various concentrations of erythrocytes were dialyzed against 6-fold diluted r-PBS for $30 \mathrm{~min}$ in the presence of a constant amount of iodinated $\operatorname{IgG}\left(2.4 \times 10^{6} \mathrm{cpm}\right)$. The total volume of a mixture of erythrocytes and IgG was $1 \mathrm{ml}$ in each case. After further dialysis against PBS, the amount of radioactivity trapped in the ghosts was determined. 
Fig. 4. Incorporation of iodinated BSA into ghosts. Erythrocyte ghosts were prepared in the presence of various concentrations of BSA. The concentrations of BSA associated with the ghosts are expressed as the radioactivities per sedimented ghost volume. These ghosts were lysed in distilled water by one cycle of freeze-thawing. The cytoplasmic fraction was separated from the membrane fraction by centrifugation at 24,000 rpm for $40 \mathrm{~min}$. $\bigcirc$, counts associated with ghosts. counts in the cytoplasmic fraction.

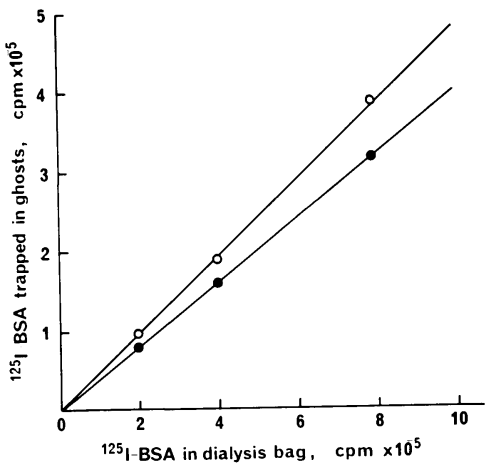

Under the phase-contrast microscope, homogeneous erythrocyte ghosts were observed at concentrations of up to $30 \%$ but many intact erythrocytes remained when the concentration exceeded $40 \%$.

Distribution of molecules trapped in ghosts. The concentration of BSA incorporated into ghosts was measured after dialysis of the erythrocytes with various concentrations of BSA. Results showed that the BSA trapped in the ghosts increased linearly with the increase in the concentration of BSA in the dialysis bag. The concentration in the ghosts was about $50 \%$ of the initial concentration of BSA in the bag (Fig. 4). This means that the amount of exogenous substance enclosed in one ghost can be controlled by varying the initial concentration of the substance in the dialysis bag. Next, the distribution of BSA was measured by lysing the ghosts in distilled water with one cycle of freeze-thawing, and by separating the supernatant cytoplasmic and membrane fractions by centrifugation at $24,000 \mathrm{rpm}$ for $40 \mathrm{~min}$. With all concentrations of BSA, about $80 \%$ of the radioacitivity was recovered in the cytoplasmic fraction. Treatment of the cytoplasmic fraction with $5 \%$ trichloroacetic acid (TCA) caused more than $98 \%$ of the radioactivity to be precipitated.

Stability of BSA in erythrocyte ghosts. Three kinds of proteases have been found in the stroma of human erythrocytes (13). Therefore, the stability of iodinated BSA enclosed in human erythrocyte ghosts was examined. When stored at $4^{\circ} \mathrm{C}$, the ghosts contained $91 \%$ and $87 \%$ of the initial amounts of radioactivity after one and four days, respectively. More than $90 \%$ of the radioactivity released from the ghosts was precipitated with $5 \%$ TCA. When these ghosts were incubated for $24 \mathrm{~h}$ at $37^{\circ} \mathrm{C}$ in Eagle's MEM supplemented with $10 \%$ calf serum, about $90 \%$ of the radioactivity leaked into the medium, and about $90 \%$ of the leaked radioactivity was precipitated with TCA. When PBS was used instead of r-PBS as the outer solution during hypotonic treatment, a similar amount of radioactivity was found in the ghosts after storage at $4^{\circ} \mathrm{C}$ overnight but more leakage occurred during longer storage. These findings suggest that the membrane structure was destroyed more rapidly at $37^{\circ} \mathrm{C}$ than at $4^{\circ} \mathrm{C}$ and more rapidly in a medium with a higher concentration of sodium ion than of potassium ion. Therefore, in subsequent experiments we usually used r-PBS for the hypotonic treatment of erythrocytes.

The molecular profile of iodinated BSA in ghosts was compared with that of the original solution by SDS-polyacrylamide gel electrophoresis. In this experiment we used ghosts stored for $24 \mathrm{~h}$ at $4^{\circ} \mathrm{C}$. As shown in Fig. 5, the two preparations gave the 


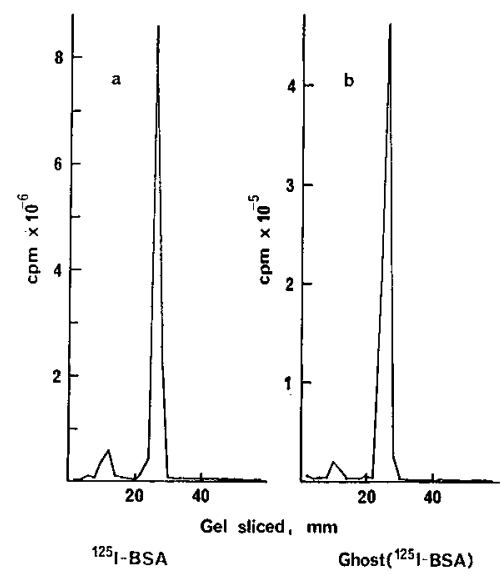

Fig. 5. SDS-polyacrylamide gel electrophoretic pattern of BSA incorporated into erythrocyte ghosts. Iodinated BSA was introduced into ghosts. After storage for $24 \mathrm{~h}$ at $4^{\circ} \mathrm{C}$, the ghosts were applied to the gel, and the radioactivity in 2-mm thick slices of the gels was counted. a) original iodinated BSA solution. b) BSA trapped in ghosts.

same pattern and no small fragments were found in the BSA sample from ghosts. These results show that the protein molecules introduced into resealed ghosts are quite stable.

Introduction of various proteins into ghosts and the ability of these ghosts to fuse with recipient cells. The surface of cells, including erythrocytes, is negatively charged. Therefore, basic proteins which have a positive charge under physiological conditions might be adsorbed on the surface of erythrocyte ghosts. To test this possibility, we treated erythrocytes by the gradual hemolysis method (22) in the presence of three proteins with different isoelectric points. Then with the immunofluorescent method, we examined whether these proteins were adsorbed on the surface of ghosts or were enclosed in the ghosts. The ghosts were stained with fluorescent antibodies to
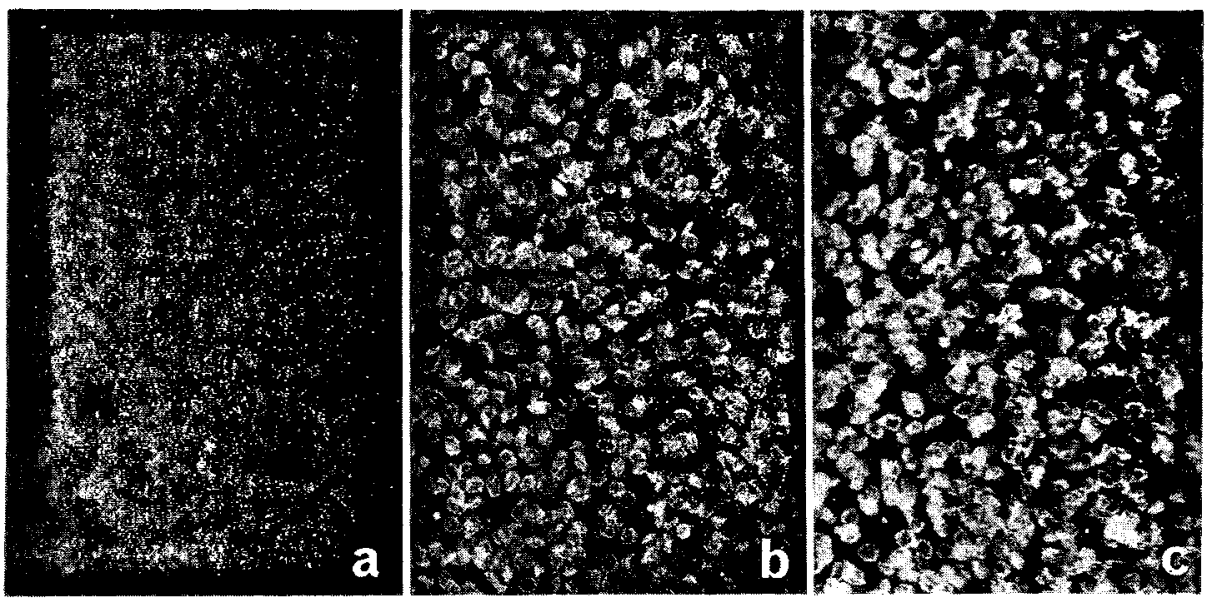

Fig. 6. Erythrocyte ghosts containing BSA. Erythrocyte ghosts were prepared in the absence of BSA (a) or in the presence of BSA (b and c). The concentrations of BSA in the dialysis bag were $0.3 \mathrm{mg} / \mathrm{ml}$ (b) and $3 \mathrm{mg} / \mathrm{ml} \mathrm{(c).} \mathrm{They} \mathrm{were} \mathrm{semared} \mathrm{on} \mathrm{the} \mathrm{same} \mathrm{slide-galss} \mathrm{and} \mathrm{air-dried.} \mathrm{After} \mathrm{fixa-}$ tion with acetone, they were stained first with anti-BSA rabbit serum then with FITC-conjugated anti-rabbit goat serum. Without acetone-fixation, no detectable fluorescence was observed in any ghosts. 
TABLE 3. INTRODUCTION OF VARIOUS PROTEINS INTO GHOSTS AND THE FUSION CAPACITY OF THESE GHOSTS

\begin{tabular}{lcccc}
\hline Protein & $\begin{array}{c}\text { Molecular } \\
\text { weight }\end{array}$ & $\begin{array}{c}\text { Isoelectric } \\
\text { point }\end{array}$ & $\begin{array}{c}\text { Concentration }{ }^{a} \\
\text { in dialysis bag } \\
(\mathrm{mg} / \mathrm{ml})\end{array}$ & $\begin{array}{c}\text { Fusion }^{b} \\
\text { capacity } \\
(\%)\end{array}$ \\
\hline BSA & 67,000 & 4.6 & 0 & 86 \\
& & & 0.2 & 76 \\
IgG & 150,000 & 7.0 & 2.0 & 84 \\
(rabbit) & & & 0 & 82 \\
& 14,600 & $11.0-11.2$ & 0.06 & 82 \\
Lysozyme & & & 0.5 & 86 \\
(chicken) & & & 0.3 & 85 \\
& & & 3.0 & 86
\end{tabular}

a Erythrocytes ghost were prepared in the presence of exogenous proteins at the concentrations indicated.

$b$ Fusion capacity was determined by measuring the percentage of recipient Ehrlich ascites tumor cells fused with these ghosts. Fusion was checked with anti-erythrocyte membrane rabbit serum.

these exogenous proteins after acetone-fixation, but were not stained without acetone-fixation. The intensity of the fluorescence increased with the increase in the initial concentration of protein in the dialysis bag (Fig. 6). This suggests that any protein can be introduced into ghosts, irrespective of its charge. As shown in Table 3, about $80 \%$ of the recipient cells consistently fused with these ghosts.

Optimal conditions for the fusion of erythrocytes or erythrocyte ghosts with plated recipient cells. When erythrocytes or erythrocyte ghosts muct be fused with plated recipient cells, the plated cells are first covered with HVJ, then free HVJ is removed, and the cells are covered with the second cell suspension. Because the essential step for cell fusion is to bridge the two cells with HVJ, the key point in increasing fusion efficiency is how to form this bridge effectively. The following factors are thought to affect this step; 1) the titer of the HVJ, 2) the concentration of the second cell suspension, 3) the duration of viral adsorption on plated cells and 4) the temperature at which the viral particles are adsorbed. Fusion efficiency increased linearly with an increase in the viral titer and the concentration of etythrocytes. HVJ was not cytotoxic when its titer was less than $5 \times 10^{3} \mathrm{HAU}$. Okada et al. observed that the hemadsorption (HA) activity of HVJ adsorbed on cells disappeared when the cells were incubated at $4^{\circ} \mathrm{C}(17)$, and that this phenomenon might reduce fusion efficiency. As expected, the optimal incubation period for viral adsorption at $4^{\circ} \mathrm{C}$ was about $4 \mathrm{~min}$; a longer incubation period did not increase fusion efficiency. An increase in temperature during the viral adsorption step greatly decreased fusion efficiency. The procedure that gave the highest fusion $(84 \%)$ of the plated recipient cells with ghosts containing FITC-BSA was as follows: Dishes, $(30 \mathrm{~mm}$ in diameter) were washed once with chilled BSS and $1 \mathrm{ml}$ of chilled HVJ $\left(4 \times 10^{3} \mathrm{HAU}\right)$ was added, after which the dishes were incubated for $4 \mathrm{~min}$ at $4^{\circ} \mathrm{C}$. Free $\mathrm{HVJ}$ was removed and $0.7 \mathrm{ml}$ of the chilled ghost suspension $(10 \% \mathrm{v} / \mathrm{v})$ was added gently after which the dishes were incubated first for $20 \mathrm{~min}$ at $4^{\circ} \mathrm{C}$, then for $20 \mathrm{~min}$ at $37^{\circ} \mathrm{C}$. More than $95 \%$ of the recipient cells could be fused with intact erythrocytes under these conditions. 
TABLE 4. EFFICIENCY OF INTRODUCTION OF IODINATED BSA INTO RECIPIENT CELLS (ETC) BY THE GHOST FUSION METHOD

\begin{tabular}{cccc}
\hline & $\begin{array}{c}\text { Initial amount } \\
\text { in bag }{ }^{a}\end{array}$ & $\begin{array}{c}\text { Amount trapped } \\
\text { by ghosts }\end{array}$ & $\begin{array}{c}\text { Amount transferred } \\
\text { to recipient cells }\end{array}$ \\
\hline $\begin{array}{c}\text { Radioactivity } \\
(\mathrm{cpm}) \\
\text { Recovery } \\
(\%)\end{array}$ & $1.6 \times 10^{8}$ & $5.3 \times 10^{6}$ & $2.5 \times 10^{5}$ \\
\hline
\end{tabular}

a $10 \%$ erythrocyte suspension in a dialysis bag was used in this experiment.

Efficiency of the introduction of exogenous molecules into recipient cells by the ghost fusion method. The over-all efficiency of the introduction of exogenous substance into recipient cells by this ghost fusion method was estimated with iodinated BSA. About $5 \%$ of the initial amount of BSA in the dialysis bag was trapped in the ghosts. After fusion of these ghosts with recipient cells, about $5 \%$ of the BSA that had been trapped in the ghosts was recovered in the recipient cells. Therefore, the final amount of BSA introduced into recipient cells was $0.25 \%$ of the initial amount in the dialysis bag. These results are summarized in Table 4.

\section{DISCUSSION}

We have here examined some characteristics of the ghost fusion method. Fig. 4 shows that the concentration of BSA trapped in the ghosts was about $50 \%$ of the initial concentration in the dialysis bag, with concentrations of up to $60 \mu \mathrm{g} / \mathrm{ml}$ (the maximal concentration used in this experiment). In more recent experiments, in which the intensity of the fluorescence of ghosts containing FITC-BSA was measured, a similar incorporation was observed with up to $10 \mathrm{mg} / \mathrm{ml}$ of BSA (Mekada, Yamaizumi and Okada, unpublished data). With $40 \mathrm{mg} / \mathrm{ml}$ of BSA in the bag, however, BSA was introduced into only some of the erythrocytes under the conditions employed. These findings support Lowenstein's report that when human erythrocytes were suspended in a saline solution containing $50 \mathrm{mg} / \mathrm{ml}$ of BSA, hemolysis was inhibited in similar dialysis steps (10). Thus, when it is necessary to prepare loaded erythrocyte ghosts in the presence of a high concentration of an exogenous substance, or when the ratio of packed erythrocytes to the total volume of the dialysis bag is high (more than $30 \%$ ), a more dilute hypotonic solution or a longer treatment in the hypotonic solution must be used.

We calculated the number of molecules of BSA introduced into a single recipient cell. With the maximal amount of BSA $(10 \mathrm{mg} / \mathrm{ml})$, assuming that one recipient cell fused with one ghost, about $4 \times 10^{6}$ molecules are introduced into a single cell. Wasserman et al. (23) calculated from the data of a similar experiment that $2.7 \times 10^{6}$ molecules of BSA were introduced per recipient cell.

When erythrocyte ghosts fused with recipient cells, their membranes became incorporated into the recipient cell membranes. Thus unexpected effects of transplanted exogenous membrane molecules on recipient cells must always be kept in mind when analysing the results. On the other hand, the erythrocyte membrane-specific molecules serve as good markers for detecting cells fused with erythrocyte ghosts. When the cell surface is treated with fluorescein-labelled antibody to erythrocyte membranespecific molecules (4), fluorescence is observed only on the surface of cells fused with 
ghosts. The numbers of molecules trapped in a single ghost can be controlled (see Fig. 4). Therefore, it should be possible to select cells with a given number of incorporated molecules, with a cell analyzer/sorter that sorts out and collects cells according to their fluorescence intensity and cell volume (8). Recently, we succeeded in collecting only recipient cells fused with ghosts with a Fluorescence Activated Cell Sorter (FACS). These recipient cells that fused with ghosts and that have been stained with flourescence antibody survive and can form colonies, like the recipient cells fused with intact erythrocytes (12).

Morrison and Neurath (13) reported three proteases in human erythrocytes, but as judged from the electrophoretic pattern of the BSA from erythrocyte ghosts, no degradation of BSA occurred during storage of ghosts containing BSA at $4^{\circ} \mathrm{C}$ for $24 \mathrm{~h}$ (Fig. 5). There are three possible explanations for this discrepancy: 1) The proteases may be inactive at the low temperature used, 2) Large proportions of these enzymes may have leaked out during hemolysis, 3) BSA may be resistant to the proteases. At present we do not know which explanation is correct.

When intact erythrocytes fused with cells, their hemoglobin rapidly was distributed throughout the cytoplasm and even the nucleus, as shown by benzidine staining. Cell division probably also results in the penetration of hemoglobin into the nuclear region, since the nuclear membrane disappears in the prometaphase of cell division. It is curious that cells appear healthy and divide normally in spite of the presence of exogenous hemoglobin. Possible degradation of hemoglobin in the cells was not examined, but BSA has been shown to be degraded in cells with a half-life of about $4 \mathrm{~h}(26)$.

Several recent reports have shown that macromolecules introduced by this method, including an enzyme (21), t-RNA (1) and an antibody (25) retain their function in the recipient cells.

\section{REFERENCES}

1. Capecchi, M.R., R.A. Vonder HaAr, N.E. Capecchi and M.M. Sveda. The isolation of a suppressible nonsense mutant in mammalian cells. Cell 12, 371-381, 1977

2. FogH, J. and R.O. Lund. Continuous cultivation of epithelial cell strain (FL) from human amniotic membrane. Proc. Soc. Exp. Biol. Med. 94, 532-537, 1957

3. FRYE, L.D. and M. EDIDIN. The rapid intermixing of cell surface antigens after formation of mouse-human heterokaryons. J. Cell Sci. 7, 319-335, 1970

4. Furusawa, M. and H. AdACHI. Immunological analysis of the structural molecules of erythrocyte membrane in mice. Exp. Cell Res. 50, 497-504, 1968

5. Furusawa, M., T. Nishimura, M. Yamaizumi and Y. OKada. Injection of foreign substances into single cells by cell fusion. Nature 248, 449-450, 1974

6. Furusawa, M., M. Yamaizumi, T. Nishimura, T. Uchida and Y. OKada. Use of erythrocyte ghosts for injection of substances into animal cells by cell fusion. In Methods in Cell Biology, Vol 14, Ed., Prescott, D.M., Academic Press, New York, pp. 73-80, 1976

7. Greenwood, F.C., W.M.Hunter and J.S. Glover. The preparation of 131I-labelled human growth hormone of high specific radioactivity. Biochem. J. 89, 114-123, 1963

8. Herzenberg, L.A., R.G.Sweet and L.A. Herzenberg. Fluorescence-activated cell sorting. Sci. Am. 234, 108-117, 1976

9. LoBue, J., B.S. Dornfest, A.S. Gordon, J. Hurst and H. Quastler. Marrow distribution in rat femurs determined by cell enumeration and ${ }^{59}$ Fe labeling. Proc. Soc. Exp. Biol. Med. 112, 1058-1062, 1963

10. Lowenstein, L.M. The effect of albumin on osmotic hemolysis. Exp. Cell Res. 20, 56-65, 1960 
11. Loyter, A., N. Zakai and R.G. KUlKa. "Ultramicroinjection" of macromolecules or small particles into animal cells. J. Cell Biol. 66, 292-304, 1975

12. Mekada, E., M. Yamaizumi and Y. OKadA. An attempt to separate mononuclear cells fused with human red blood cells-ghosts from a cell mixture treated with HVJ (Sendai virus) using a fluorescence activated cell sorter (FACS II). J. Histochem. Cytochem. 26, 62-67, 1978

13. Morrison, W.L. and H. Neurath. Proteolytic enzymes of the formed elements of human blood. J. Biol. Chem. 200, 39-51, 1953

14. Murayama, F. and Y. OKadA. Efficiency of hybrid cell formation from heterokaryons fused by HVJ. Biken J. 13, 1-9, 1970

15. Nishimura, T., M. Furusawa, M. Yamaizumi and Y. Okada. Method for intracellular injection by cell fusion using erythrocyte ghosts. Cell Struct. Funct. 1, 197-200, 1976

16. OKada, Y., J. Kim, Y. Maeda and I. KoseKi. Specific movement nt of cell membranes fused with HVJ (Sendai virus). Proc. Natl. Acad. Sci. USA 71, 2043-2047, 1974

17. OKada, Y., I. KoseKi, J. Kim, Y. Maeda, T. Hashimoto, Y. Kanno and Y. Matsui. Modification of cell membranes with viral envelopes during fusion of cells with HVJ (Sendai virus). I. Interaction between cell membranes and virus in the early stage. Exp. Cell Res. 93, 368-378, 1975

18. Okada, Y. and F. Murayama. Requirement of calcium ions for the cell fusion reaction of animal cells by HVJ. Exp. Cell Res. 44, 527-551, 1966

19. Orkin, S.H., F.I.HARosi and P.Leder. Differentiation in erythroleukemic cells and their somatic hybrids. Proc. Natl. Acad. Sci. USA 72, 98-102, 1975

20. SALK, J.E. A simplified procedure for titrating hemagglutinating capacity of influenza-virus and the corresponding antibody. J. Immunol. 69, 87-98, 1944

21. Schlegel, R.A. and M.C. Rechsteiner. Microinjection of thymidine kinase and bovine serum albumin into mammalian cells by fusion with red blood cells. Cell 5, 371-379, 1975

22. Seeman, P. Transient holes in the erythrocyte membrane during hypotonic hemolysis and stable holes in the membrane after lysis by saponin and lysolecithin. J. Cell Biol. 32, 55-70, 1967

23. Wasserman, M., N. Zakai, A. Loyter and R.G. KulKa. A quantitative study of ultramicroinjection of macromolecules into animal cells. Cell 7, 551-556, 1976

24. Weber, K. and M. Osborn. The reliability of molecular weight determinations by dodecyl sulfate-polyacrylamide gel electrophoresis. J. Biol. Chem. 244, 4406-4412, 1969

25. Yamaizumi, M., T. Uchida, Y. OKada and M. Furusawa. Neutralization of diphtheria toxin in living cells by microinjection of antifragment A contained within resealed erythrocyte ghosts. Cell 13, 227-232, 1978

26. Yamaizumi, M., T. Uchida, Y. Okada, M. Furusawa and H. Mitsui. Rapid transfer of nonhistone chromosomal proteins to the nucleus of living cells after their introduction by cell fusion with erythrocyte ghosts. Nature 237, 782-784, 1978

27. Yamanaka, T. and Y. OKada. Cultivation of fused cells resulting from treatment of cells with HVJ. I. Synchronization of the stages of DNA synthesis of nuclei involved in fused multinucleated cells. Biken J. 9, 159-175, 1966 